Article

\title{
Putting Phosphorus First: The Need to Know and Right to Know Call for a Revised Hierarchy of Natural Resources
}

\author{
Friedrich-W. Wellmer ${ }^{1, *}$ and Roland W. Scholz ${ }^{2,3}$ \\ 1 Formerly Federal Institute for Geosciences and Natural Resources (BGR), Neue Sachlichkeit 32, \\ D-30655 Hannover, Germany \\ 2 Department for Knowledge and Communication Management, Danube University Krems, \\ Dr.-Karl-Dorrek-Straße 30, 3500 Krems, Austria; roland.scholz@emeritus.ethz.ch \\ 3 Fraunhofer Institute for Interfacial Engineering and Biotechnology (IGB), Nobelstraße 12, \\ 70569 Stuttgart, Germany \\ * Correspondence: fwellmer@t-online.de; Tel.: +49-511-390-6479
}

Academic Editor: Cara Beal

Received: 1 April 2017; Accepted: 30 May 2017; Published: 4 June 2017

\begin{abstract}
The aim of this paper is to develop two concepts regarding phosphorus that will serve as a contribution fulfilling the call for intergenerational equity: to improve knowledge of future resources and to develop a framework by setting priorities for maximizing availability with a hierarchy of natural resources. The increasing human demand for minerals and metals is causing persistent concern about long-term supply security. This holds true particularly for phosphorus. Phosphorus is bioessential; it cannot be substituted. There are no unlimited resources for phosphorus. The question of how large the reserves are and the potential for finding additional reserves and resources for a long-term supply are, therefore, of interest to numerous stakeholders, from governments to individuals. We examine governments' needs and individuals' rights to know private exploration data. Because of the essential nature of phosphorus, we emphasize the public's special right to know as much as possible about phosphate reserves, resources and the geopotential for new discoveries, based upon the basic human right to feed oneself in dignity. To fulfill the call for intergenerational equity, however, knowledge alone is not enough; guidelines for management have to follow. This can be achieved by defining a hierarchy of natural resources for setting priorities. For humankind's technological and cultural development, a sufficient supply of energy resources must be considered the key element; therefore, efforts to maximize information that will enable best decisions to be made have been the strongest. A hierarchy of natural resources with fossil and nuclear energies at the top was proposed. However, with the new development of renewable forms of energy and the decreasing role of fossil-fuel energy, the hierarchy of natural resources that defines priorities must be revised. We propose a hierarchy that replaces fossil-fuel energy at the top with phosphorus.
\end{abstract}

Keywords: phosphorus; phosphate; raw materials for energy; right to know; need to know; reserves; resources; geopotential; hierarchy of natural resources

\section{Introduction}

Humankind has always depended on the use of energy and mineral resources for its technological and cultural evolution. Since governments have a responsibility to protect their citizens' basic rights and to act on behalf of the benefit of their people, they must care for the foundation of their citizens' well-being. The material foundations for meeting these basic requirements include water, air, and soil—the renewable biomass resource for nourishment—heating, tools, building and shelter or, 
formerly, for smelting and shipbuilding, and non-renewable energy and mineral resources. Therefore, with increasing industrialization in the 19th century, all industrial nations launched geological surveys [1]. Often, these were the first scientific "ministries" or government organizations to be established universities. Their task was to supply basic geoscientific information for supporting private and state enterprises to develop natural resources and to discover new ones as well as to provide governments with impartial advice. The first geological survey was the forerunner of the British Geological Survey founded in 1835 [2]. However, in some countries, such as Sweden, early "laboratories" had been established as early as the end of the 17th century to deal with the efficient use of metals and the problems related to mines and mining [3]. Supplying a nation with mineral resources in market-economy countries is normally the task of industry. Government supplies only the fundamental data produced by geological surveys or other research institutions and sets framework conditions, such as rules and regulations for access to natural resources. The days when a quantitative estimate of mineral and energy resources could be made just from surficial observations and mapping by geological surveys are long past. Today, exploration to depth by drilling is necessary to detect and define deposits worth exploiting. With a few exceptions, such explorations are conducted by private industries and are activities that come with high risks. One example can be taken from the oil industry. Formerly, the success ratio quoted was between $20 \%$ and $35 \%$ [4,5]. Presently, due to technological improvements and innovations such as 3D seismics and refined visualization technology, some companies claim that, in certain cases, the success rates have increased to $50 \%$ or more [6]. However, in its recent report on the global oil supply, HSBC Global Research [7] reported that the worldwide success rate, which fluctuated around 20\% from 1960 to 2010, has plummeted to an all-time low of only $5 \%$. In base metal or precious metal explorations, expenditures related to the exploration techniques with only shallower depth-penetration capabilities and, consequently, shallower drill holes, are much lower, but the risks are higher [8]. If a drill target is identified, the risks are about 1:90 [9].

As a consequence, over time, a division of labor has developed. Governments supply regional geoscientific data (geological, geochemical and geophysical maps) in the forefront of industrial activities, and companies concentrate on detailed high-risk exploration for outlining deposits. However, in addition, in order to be able to stepwise concentrate on smaller and smaller target areas to finally outline a deposit using expensive drilling programs, companies must conduct regional surveys such as seismic surveys in hydrocarbon exploration or electromagnetic airborne surveys in metal exploration. Moreover, due to the numerous and high exploration risks outlined above, there is a great volume of regional and detailed exploration data that does not lead to discoveries, yet could be useful for future exploratory campaigns. $\diamond$

As a result of this analysis, in regard to the ownership of exploration data, we can state the following:

- Governments own basic geological data collected by their geological surveys and other government research institutions derived from their own work, and these are free to the interested public.

- Private companies own

$\diamond \quad$ Data related to their deposits in exploitation or nearing exploitation, which, in Figure 1 below, will be defined as reserve data;

$\diamond$ Data related to deposits that are not economic at the present time, which in Figure 1 below will be defined as resources (sensu stricto); and

$\diamond$ Regional exploration data from their exploratory campaigns.

Because the availability and supply of natural resources are basic to our lives and concerns, the question arises: what is involved in the needs of governments and the rights of the public to have access to private data concerning natural resources? To answer this question, first we will further scrutinize the character of exploration data, especially the most sensitive data, namely, the reserve 
data of companies. We then ask whether one has to distinguish the importance of data according to commodities and consequently arrive at conclusions concerning arguments regarding governments' needs to know and the public's basic right to know at least certain private data. We further examine why certain data are critical with a consequence for the hierarchy of natural resources.

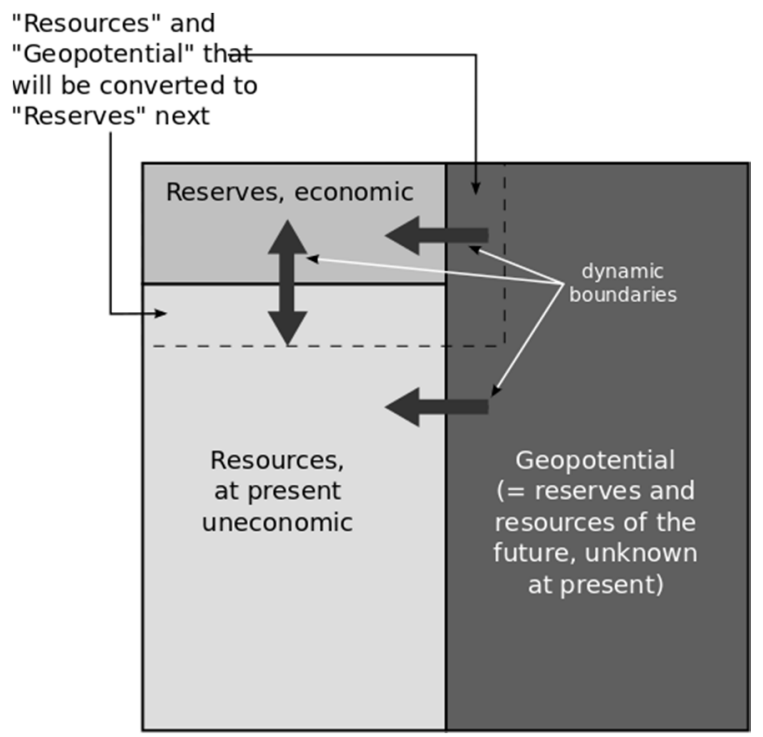

Figure 1. The Total Resource Box $[10,11]$; the $x$-axis is the general trend of increasing geological knowledge, going from right to left; the $y$-axis is the general trend of increasing economic viability, going from bottom to top. In general, the concept of the Total Resource Box is based on the McKelvey Box used by the US Geological Survey (see, e.g., [12]), based on earlier depictions [13-15] or the United Nations Framework Classification for Energy and Mineral Resources [16]. It has, however, been simplified and modified to make it more understandable to politicians and laypersons.

\section{Characteristics of Exploration Data}

\subsection{Characteristics of Detailed Exploration Data, Especially of Economic and at Present Uneconomic Deposits}

Mining investments are very capital-intensive, frequently requiring sums in the hundreds of millions or even billions of dollars. Therefore, to minimize the investment risk, the tonnage and grade data of a deposit have to be determined with a relatively high degree of accuracy during exploration in order to justify such high investment costs. During the course of exploration, many occurrences are discovered, but only a small part of these may be economically feasible to exploit. Accordingly, based on the currently available knowledge and economics, we can distinguish three categories in the Total Resource Box (Figure 1). (Unfortunately, in the international literature, the term "resources" is used with two meanings: resources without established economic viability (now called resources sensu stricto) and total resources comprising everything from reserves to geopotential, and referring also to presently unknown reserves and resources (sensu stricto)). Thus, we can cover all the resources that are available on Earth with the following illustration:

(a) Reserves are defined as the category of total resources that can be economically extracted with proven technology and current economics (including available energy and environmentally and socio-economically acceptable conditions);

(b) Resources (sensu stricto) are known (at various levels of certainty), but are not economically viable at present; and

(c) Geopotential is not yet known but, by geologic reasoning, it can be expected to contain deposits that will be discovered by modern exploration technologies in the future. 
Figure 1 illustrates the interrelationship and dynamics of reserves, resources (sensu stricto), and geopotential; the area contained by the dashed line outside the reserves box denotes the resources (sensu stricto) and geopotential that will be converted to reserves next. The boundaries are always dynamic, influenced by new technologies and/or price developments: what are resources today can be reserves tomorrow and vice versa, underlining the risks that mining companies encounter. This applies also to the boundary between geopotential, reserves and resources. As a result of exploratory work or technological development, geopotential can become reserves and resources or it may not. Consequently, the number of reserves and resources can represent only a snapshot within the dynamic process of resource evaluation.

As outlined above, budgets for exploration are generally private funds. The aim of companies is to maximize the returns of their shareholders rather than to determine as many reserves or even resources as possible. They decide how much exploration to conduct in detail to minimize the risk of a mining investment, which is always higher than for a normal industry investment [17]. Therefore, the amounts of reserves defined are determined solely by the interests of companies to minimize risks and maximize returns. For them, reserves are their working inventory. Therefore, they normally gather data and estimate reserves for only as many years of production as the cost associated with obtaining the data and their preference for business planning justify, i.e., the reserves may be more dependent on business planning models and investment alternatives than on the magnitude of minerals in the ground. These reserves usually have to comply with internationally accepted reporting standards, such as those from Australia (the JORC-Code) or Canada (National Instrument NI 43-101) [18,19].

\subsection{Characteristics of Regional Exploration Data}

Regional geoscientific data such as geological, geochemical or geophysical maps always represent the knowledge about an area at a certain time, and geological knowledge, in particular, increases over time. Geochemical and geophysical exploration methods improve and, consequently, the data output increases. These regional data are the basis for generating exploration ideas and concepts for the so-called grassroots step, which is the start of every exploration campaign. Grassroots spending is associated most strongly with new discoveries. Developing exploration concepts is a learning process [20] (Figure 2), and it is quite natural for several paradigm changes to occur before a drilling campaign finally yields positive results; in addition, paradigm changes very often begin with basic data.

\section{Consecutive learning curves in technology and exploration}

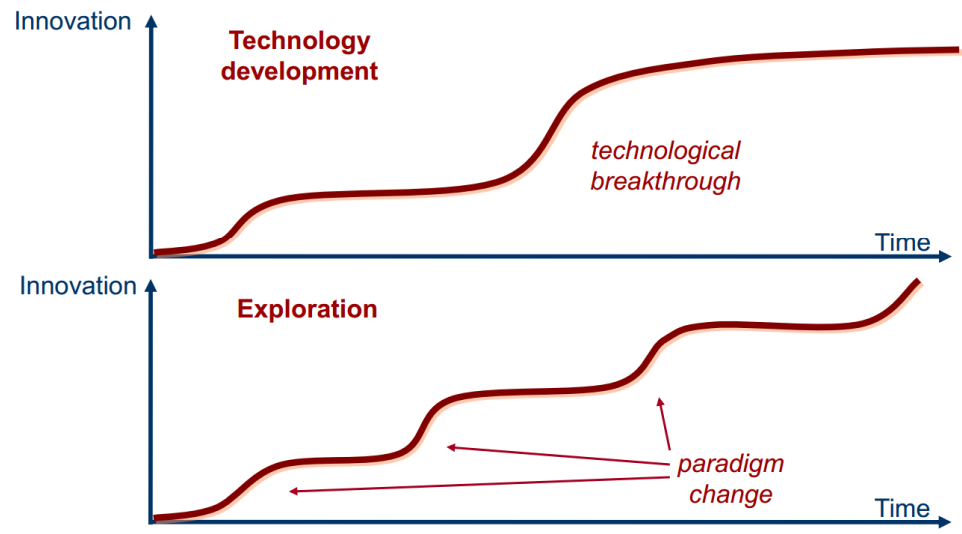

Figure 2. Consecutive learning curves in technology and exploration.

To illustrate the typical learning processes in exploration with paradigm changes, an example is given for a more advanced project stage, the so-called brown-field exploration (Figure 3). Sillitoe [21] published an interesting case history about exploration successes for precious and base-metal deposits in the Circum-Pacific Region. He lists the number of companies involved in each prospect from the 
start of exploration to its successful end with an economically successful mining operation (Figure 3). Each company represents a learning curve; a new company brings in new ideas and creates a change of paradigm. The analysis by Sillitoe [21] demonstrated that less than $50 \%$ of the prospects went through this learning curve only once; the extreme was 10 times, i.e., several changes of paradigm were necessary to finally be successful.

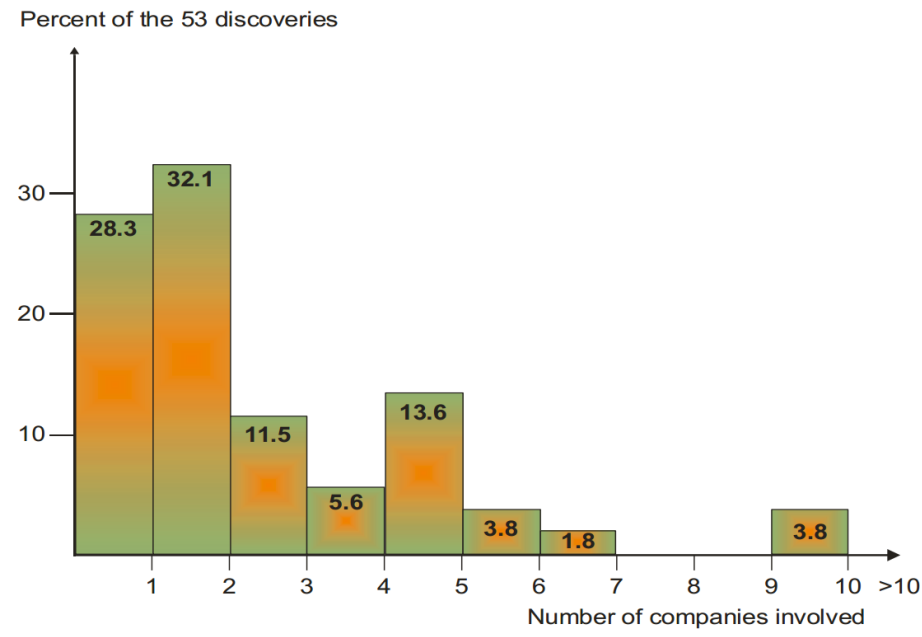

Figure 3. The number of companies involved from the start of exploration to its successful conclusion for 53 base-metal and precious-metal discoveries in the Circum-Pacific Region (after [21,22]).

\section{The Significance of Exploration Data Dependent on the Type of Resources}

After these principal discussions about the character of natural resources data, we will study specific groups of natural resources and examine whether aspects of needs and rights to know can be derived from the perspectives of their characters. We differentiate natural resources, i.e., energy and mineral resources, as three categories [23] (Figure 4).

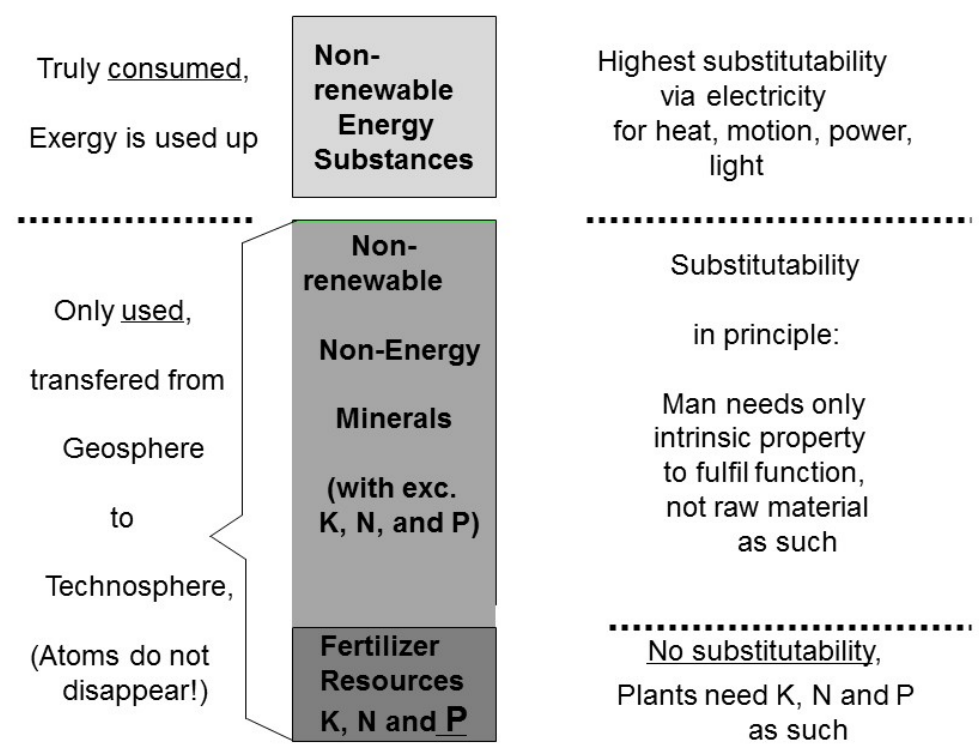

Figure 4. Classification of natural resources according to their recyclability and substitutability [23].

- Energy minerals. These are the fossil fuels-oil, natural gas, coal, and radioactive elements for generating nuclear power. These are truly consumed; their exergy is used up. However, they 
have the highest substitutability. Via electricity, the premium energy source, all energy sources can fulfill the functions of heating, motion, lighting and power for, e.g., information technology.

- Mineral resources with the exception of the fertilizer elements nitrogen, potassium and phosphorus. Humankind generally does not need these raw materials as such to perform a function but only their intrinsic properties e.g., for copper, the property to conduct electric currents. This aspect offers a broad field for creative substitutions for the functions of raw materials.

- The fertilizer elements nitrogen, potassium and phosphorus used in agriculture. Plants require these elements; they cannot be substituted. All three elements are as essential for life as water and air. There are other beneficial elements that support plant biomass growth, the micronutrient elements calcium, sodium, magnesium, sulfur, boron, chlorine, iron, manganese, zinc, copper, molybdenum, nickel, cobalt, and selenium. They are beneficial, but are not really necessary for life [24]. Their main use is in other areas and, therefore, they are considered as belonging to the second category.

For the aim of this paper, the first and last categories, energy and fertilizer resources, are the most important ones.

For humankind's continuing technological and cultural evolution, a sufficient supply of energy resources must be considered the key element [25]. Societies continue their development with the consumption of increasing amounts of energy. Only mature societies with a high percentage of their industries in the service sector are capable of decoupling their gross national product from the consumption of energy. With enough energy, all recycling problems can be solved because atoms of mineral resources are not lost. Metals are used, not consumed. With enough energy all water problems can be solved; used water can be recycled, and saltwater which is ubiquitous, can be desalinated. The copper mines of Chile, the largest copper producer in the world, might serve as an example. Many mines are located in arid areas and rely increasingly on desalinated water [26]. Sufficient and affordable energy is the key to global equity and a stage of sustainable development [25].

This is the reason governments focus especially on energy matters. The US for example has a special energy ministry, the Department of Energy (DOE). There are regular reports by the DOE and investigations of potentially critical energy materials (e.g., [27]). In Germany, the economics ministry also stresses the importance of energy, in this case fossil-fuel and renewable energies, with its title of Ministry of Economics and Energy. Furthermore, at the international level, the International Energy Agency (IEA) regularly analyses the world's energy situation and its future path [28]. With similar analyses, the organization of the World Energy Council functions at the international industry level [29].

The situation is different for phosphorus. Whereas for energy resources, substitutability is a maximum factor (all forms of energy can fulfill the functions needed to create heat, power or light directly or indirectly via electricity), it is non-existent for the three macronutrient elements nitrogen, potassium and phosphorus. Each is bio-essential and bio-essential elements are those that are indispensably and unsubstitutably involved in any organism's metabolism or enzyme activation, i.e., they are essential elements for food production and thereby for sustaining life. While there are practically unlimited and exploitable resources in seawater for potassium and in the air for nitrogen, the same is not true for phosphorus. Primary phosphorus is found predominantly in the mineral apatite, which occurs ubiquitously in many rock types. However, in order to be of economic interest, local enrichment processes must have taken place to form mineable deposits of phosphate rock. In regard to secondary phosphorus, we are currently at the boundary of the economical recycling of phosphorus from municipal wastewater with concentrations of about 5 and $10 \mathrm{mg}$ total phosphorus (TP) per liter [30,31]. Natural TP concentration in rivers (which depend mostly on rainfall and specific geological settings) are in the range of magnitude between 5 and $50 \mu \mathrm{g} \mathrm{TP} / \mathrm{L}$ [32], whereas average surface seawater amounts to a magnitude of $1 \mu \mathrm{g} \mathrm{TP} / \mathrm{L}$ [33], which is a factor of 5000 to 10,000 less than sewage water. Thus, the economical recycling of $P$ from aquatic systems seems to be impossible in the mid-term future. Consequently, there are no practically unlimited resources of phosphate on Earth $[34,35]$. 
Since, in the above, we consider energy and fertilizer resources to be the most important natural resources categories, one might wonder why we did not consider the aspect of the different energy intensities of fertilizer resources, but rather focused only on geological availability. Indeed, nitrogen fertilizer produced from nitrogen in the air via the Haber-Bosch-synthesis requires much more energy than phosphate or potassium fertilizer produced mostly from rock deposits via mining and benefication. The reason is this: with the changeover to renewable energies due to the "Energiewende", the changeover to renewable energies, discussed below in Sections 6 and 7, energy loses its overall importance. This is why we propose a new hierarchy of natural resources in Section 7.

\section{Governments' Needs and Rights to Know in Order to Fulfill Their Obligations}

Because governments must act for the benefit of their people, they have to formulate and pursue economic policies based on the best available facts. Consequently, there is not only a need but also a right of government authorities to know and to obtain private, often commercial and possibly sensitive, geoscientific and statistical data in order to be able to conduct "good politics" based on as many facts as possible. Such data might not be made public, or they might be made public in an aggregated form in order to prevent divulging sensitive data. For example, in the Mineral Commodity Summaries of the US Geological Survey (e.g., [12]), the most widely accepted standard publication on US and worldwide mineral production and reserves, statistical data are withheld to avoid disclosing proprietary company data in case there are too few respondents to official requests for data [35]. In general, the national government show different strategies with respect to making reserves and resources data publicly available. Here, we also have to consider that the data may be used as strategic means both for domestic and foreign economics and politics (see below).

From the above analysis in Section 3, it is evident that governments need the best possible information, especially in the case of energy data including reserve and resource data of fossil-fuel deposits.

Governments' need for information concerning natural resources in general and reserves and resources specifically exists on various levels. The following are examples:

- Economic and finance ministries want to know the reserves (and resources as future possible reserves) as an element of economic activity, as a source of employment and as future tax contributors or on the contrary as a potential tax burden if subsidies are required for economic or national security reasons, as was the case of the German hard coal mines that will be closed in 2018;

- Regional planning authorities must often plan far ahead. Therefore, they need to have a very long-range outlook. The quantities of natural resources have to be identified as economically extractable before planning permits are granted. However, the "modifying factors" (e.g., legal, environmental, social, and governmental factors, which are required for reserves under internationally accepted reporting standards, such as those from Australia (the JORC-Code) or Canada (National Instrument NI 43-101) $[18,19]$ ) are not in place yet-the task of such government bodies is to clarify the aspects of the "modifying factors."

- Geological surveys are the guardians and trustees of the geoscientific database for their countries. In order to give their governments the best possible impartial advice, they should have the best possible database. Therefore, all private exploration data be it regional or local should be recorded with geological surveys or other governmental offices, such as mining recorders. An example where an excellent database is required is when new license areas for hydrocarbon exploration are put up for bidding, as is the case for offshore exploration for example in the USA, Canada, The Netherlands or Norway or for certain mineral permits in Finland.

Not only do institutions have a right to know; under special conditions, individuals do as well, which we will discuss in the next section. We consider the individual citizen's right to know about the accessibility of important and essential (i.e., non-substitutable) mineral materials as a cornerstone 
of society's supply security. Figure 5 presents the interplay of activities and regulatory mechanisms among key actors as a prerequisite of long-term supply security.

\begin{tabular}{|c|c|}
\hline Human Species & $\begin{array}{l}\text { Is on the way building globally binding rules (laws) such as the } \\
\text { Univ. Decl. of Human Rights ("feed in dignity") or Paris United } \\
\text { Nations Convention on } 2^{\circ} \mathrm{C}\end{array}$ \\
\hline Society & $\begin{array}{l}\text { National leaders'/governments' role is to } \\
\text { economics (e.g., markets) and security of food supply, e.g., by } \\
\text { government funds for buffer stocks } \\
\text { - Provide information to citizens to become democratic actors } \\
\text { (Right to Know) }\end{array}$ \\
\hline Institution & $\begin{array}{l}\text { To institute Geological surveys (GS) that work as trusties of } \\
\text { geological data }\end{array}$ \\
\hline Organizations & $\begin{array}{l}\text { Mining companies utilize GS data for market decisions (e.g., } \\
\text { exploration needs) and provide data to GS and (in some countries) } \\
\text { to stock exchanges }\end{array}$ \\
\hline Individual & $\begin{array}{l}\text { The Right to Know is needed for educated citizenry in democratic } \\
\text { societies for (i) making meaningful/reasoned political decisions } \\
\text { (e.g., in elections), and (ii) regulation the individual exposure to } \\
\text { public endangerment (e.g., environmental threats) }\end{array}$ \\
\hline
\end{tabular}

Figure 5. The individual's right to know as a cornerstone of multi-level management in democratic societies. The levels of human systems (boxes on the left) have developed over the history of humankind based on increasing technological development [36,37]; some key actors are presented in italics.

\section{The Public's Need and Right to Know about Reserve and Exploration Data}

\subsection{General Aspects Concerning All Commodities}

The pressure to make reserve data public generally does not come from governments but from stock exchange regulations for public companies. In some countries, for example, in Sweden, Finland and Norway, private mining industry associations have been proactive and have established rules that were accepted and adopted by stock exchanges. This allows investors to base their investment decisions on sound information because reserve numbers are the fundamental data of a mining company. This rule applies to natural-resources companies in Anglo-American countries including the US, Canada, Australia, and South Africa. However, in other countries such as Germany, which has been a significant base-metal producer, mining companies have not been obliged either by government or stock-exchange regulations to make reserve data public. Furthermore, such companies have not even been required to inform government authorities on a confidential basis [35].

As discussed above in Section 2.2, exploration is a learning process. For a country's benefit, its government should have an interest in stimulating this learning process by making available to the public as much exploration data as possible. Governments must balance on the one hand the expectation of companies that the data they deliver to the government will remain confidential and, on the other hand, the desire to stimulate exploration, i.e., economic development as much as possible. In most countries, this problem is solved in such a way that companies are obliged to adhere to work commitments regarding their concessions. The data regarding their exploration commitments have to be filed with government organizations and are kept confidential for as long as the companies pursue their exploration. In the event that companies relinquish their concessions, the exploration data are made available to the public after a certain waiting period such as one to three years. This is the case, for example, in Canada, Australia, New Zealand, Norway, Sweden, Finland and Serbia. 


\subsection{The Special Case of Phosphorus}

The case of phosphorus differs from that of energy. Here, a more basic right to know applies. As outlined in Section 3, the three macronutrient elements nitrogen, potassium and phosphorus are as essential as water or soil for growing food. There are no substitutes for them. While there are practically unlimited and exploitable resources in seawater for potassium and in the air for nitrogen, this is not true for phosphorus. Because of its non-substitutability, an important element of flexibility of the feedback control cycle of the mineral supply is also missing. The feedback control cycle of a mineral supply is a mechanism by which, in the event of shortages and, consequently, price peaks, a new price equilibrium is reached by reactions on the supply and demand side [23,38]. Substitution is an element of reaction on the demand side. Consequently, in the event of shortages, more violent price peaks have to be reckoned with than with other commodities.

Starting from the International United Nations Covenant on Economic, Social and Cultural Rights that everyone is entitled to feed himself or herself in dignity [39], the basic right to know the geopotential of phosphorus in order to ensure food-supply security has been derived and postulated [35]. It is as fundamental as the right to clean air, water and soil [40]. Feeding oneself in dignity involves two human rights: an absolute one-to feed oneself as such, and a relative one- to feed oneself in dignity [41]. Feeding oneself in dignity is influenced by cultural and economic developments. It differs in the cultures of the West, East Asia or Africa, and it differs, if one considers the time 500 years in the past or in the third millennium. However, feeding oneself is an absolute right and a biological necessity. Therefore, the right to know the geopotential of phosphorus is derived not only from a relative human right, but also from an absolute one.

On a historical note, the need to feed miners played an important role in the 17th and 18th centuries in one of the most important silver-mining districts in Central Europe, the Upper Harz mining district in Germany. The mining authorities secured this basic right by storing vast amount of grains, so that miners could buy grain at a fixed price, even in times of hardship, for example, during droughts [42] (see Figure 6). It is also of interest to realize that miners' strikes in the 17th and 18th centuries in the Harz mining district were less violent than in other mining districts with no grain supplies at constant prices, which is attributed to the fact that the basic right to food had been secured here [43].

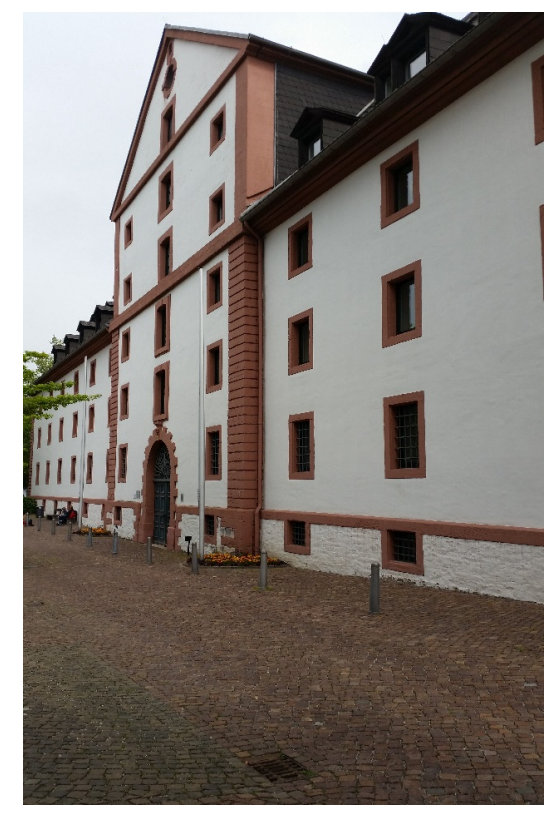

Figure 6. Granary at Osterode/Germany for storing grain for miners of the Upper Harz silver mines (built in $1733 / 34$, photo by F.-W. Wellmer). 
We will now first explain where the general right to know comes from and then we will outline a practical proposal for ensuring this right in relation to phosphorus.

\subsubsection{The Right to Know}

The right to know is considered a basic regulatory rule in the frame of democratic and free market-based societies [35]: “... the right to know ... is a significant method for seeking the truth, or at least for seeking the better answer. It is necessary for collective decision making in a democratic society" [44]. The concept of the right to know as constitutional law emerged early in Anglo-American constitutional history. In the 17th century, citizens were asking for information as "a dauntless press struggled to circumvent the official prohibition on reporting the actions of the House of Commons and the House of Lords ([45], p. 3). Since that time, a long period elapsed until its first explicit recognition in 1943 and again in 1969 (here when referring to environmental pollution), when the Supreme Court declared, "It is now well established that the Constitution protects the right to receive information and ideas" [46].

Although, for a long time, the press was seen as an agent for the people's right to know, beginning in the early 1950s, the challenge to provide information was discussed in various contexts, such as a patient's right to know the risks of a particular surgical procedure or a citizen's right to know about a neighbor's status on a crime registry. In 1962, Rachel Carson's book Silent Spring focused on the need for data about the environmental and public health impacts of chemicals, and about twenty years later, a series of environmental accidents such as the 1984 Bhopal disaster reinforced that need. In 1986, the US Congress passed the Emergency Planning and Community Right-to-Know Act (EPCRA), but another fifteen years elapsed before the EU signed the UN Aarhus Convention on 30 October 2001, granting people the right to review environmental information held by public authorities $[35,47]$.

\subsubsection{A Practical Way to Ensure the Right to Know Regarding Phosphorus}

The proposal by Wellmer and Scholz [35] to make phosphorus exploration data available to the public has recently been endorsed by the top German national scientific academies (acatech-the National Academy of Science and Engineering, the German National Academy of Sciences Leopoldina, and the Union of the German Academies of Sciences and Humanities) in their joint project for the German government, "Energy Systems of the Future (ESYS)." In their position paper titled "Raw materials for the energy systems of the future-roads for a secure and sustainable supply with raw materials," bioenergy is also addressed and, therefore, the problem of a future sustainable supply of phosphate as well. In its options for actions by the German government, the initiation of an international monitoring process of the geopotential has been proposed [48].

As outlined above, phosphorus is bioessential and there are no practically unlimited phosphorus reserves on Earth such as there are for nitrogen and potassium. However, the reserves are very large, nearly 70 billion $t$ and the resources more than 300 billion $t$ [49]. The reserve-to-consumption ratio, although only a snapshot of a dynamic system, but suitable as an early-warning indicator [34], is very high, larger than 300, and higher than for almost all other commodities. Therefore, it is not very meaningful to discuss whether or not the reserve data made public are reliable and where the boundary between reserves and resources (sensu stricto) (Figure 1) should be set. [50,51]. Due to their dynamic nature, most of the resources will be converted to reserves over time by more exploration anyway. Rough estimates of the largest known P deposits in the US and Morocco show that larger parts of the current resources of phosphate rock may turn into reserves (in the time window after 300 years) given that proper geological knowledge, geotechnologies, and price increases are assumed [51]. Michael C. Mew, one of the leading experts concerning the worldwide phosphate situation, concludes [52] "I believe the term 'reserves' has little relevance to the debate over long-term PR (phosphate rock) adequacy."

Therefore, it seems appropriate to focus on their geopotential as the progressive source of future reserves rather than on meticulously assessing the amount of (abundant) reserves today. A meaningful vision would entail a solidly funded, international standing committee that would regularly analyze 
the global geopotential of phosphorus. Such a committee could be established under the auspices of the International Union of Geological Sciences (IUGS) or initially anchored at EuroGeoSurveys (the Association of the European Geological Surveys), which has an office with a small scientific staff in Brussels, but could build on support from large resources of the national European geological surveys. An international science reference seems meaningful, as the basic data produced should not be biased by economic or national interests. A historic example is Project 156, "Phosphate deposits of the world", of the International Geological Correlation Programme from 1977 to 1984 [53]. In addition, all quantitative data about known deposits and occurrences close to the category of ore deposits could be regularly compiled as in the International Strategic Minerals Inventory (ISMI) study of phosphate of 1986 [54].

\section{A Hierarchy of Natural Resources}

In the preceding sections, we have built a case for special knowledge of the public by arguing that phosphorus is a particular issue because of its non-substitutability as a bio-essential element with no unlimited reserves on Earth and because of the basic right to feed oneself, absolutely and in relative dignity. However, knowledge about this element's long-term availability is not enough. Also needed is a management framework tool to fulfill the responsibility of intergenerational equity as demanded by the United Nations report entitled "Our Common Future", also known as the Brundtland Report [55], and to provide guidelines for formulating practical micromanagement tools. Saving one raw material or maximizing use of primary and recovery of secondary material frequently encompasses investing more of other resources, meaning that priorities have to be set. As an example, the introduction of renewable energies for the "Energiewende" will be presented. "Energiewende", a German word, now also used in the Anglo-Saxon media [56], means practically "energy transformation":

According to the understanding of most Germans, it implies the goal of the German government as a pioneer for renewable energies that, by $2050,60 \%$ of total energy consumption and $80 \%$ of electricity consumption in Germany will be produced by renewable energy sources [57]. At the same time, Germany is pursuing its goal to double raw-material productivity (ratio of total raw material consumption and gross domestic product) by 2020 (compared with the 1994 baseline) [58]. However, renewable energies require more mineral resources per unit of energy output than fossil fuels or nuclear energy [59-61]. Their use also entails accepting higher risks. Several raw materials essential for the production of renewable energies are connected with higher risks; even considering OPEC as one country, the Herfindahl-Hirschman Index (HHI) as a measure of concentration is about 2100 for oil, but for Rare Earths, for example, the HHI is over 7000 and for lithium and cobalt over 3000. Although it can be argued that, in market economies, countries generally do not make decisions about mining and exploration, and, therefore, the emphasis on geographical HHI is overstated, through the mergers of mining companies, country concentration can easily lead to company concentrations. A company already present in one country always has a competitive edge in the cases of takeovers. The fact that country concentration can lead to company concentration is later shown in Section 7 and Figure 10 for phosphate. In addition, the Worldbank Governance Indicators are worse for many metals that are more critical for renewable energies than for oil or gas [48,62].

Setting priorities means developing a hierarchy of natural resources; as in the case of the "Energiewende", the introduction of renewable energies is more important than raw material productivity. A hierarchy of natural resources can be viewed from several perspectives. It may be viewed as a precautionary tool under environmental aspects as shown with the case above of the "Energiewende" or as a precautionary tool from a supply security perspective. The hierarchy then places at the top those resources for which accessibility is believed will become critical and could cause severe difficulties from a sustainable development perspective. In addition, it can be viewed as an economic regulatory management tool to achieve the optimum output considering a wide range of different resources. 
Because of the overall importance of energy, discussed in Section 3, a four-level hierarchy of natural resources was proposed in 2009 (Figure 7) with conventional energy resources at the top [63]. This example shall be used as a model to develop a hierarchy of natural resources taking the future development of renewable energies and the importance of phosphorus into account. In the example of conventional energy sources, considered until now as the most critical and therefore placed at the top of the hierarchy in Figure 7, these are followed by raw materials that have developed over geological time and enrichment processes, e.g., metals but also phosphate. The third level comprises material available in almost unlimited amounts on Earth, such as sand for construction, but also nitrogen in the air or potassium in seawater. The lowest level represents waste and residual materials from the technosphere that are potential raw materials for secondary use [63].

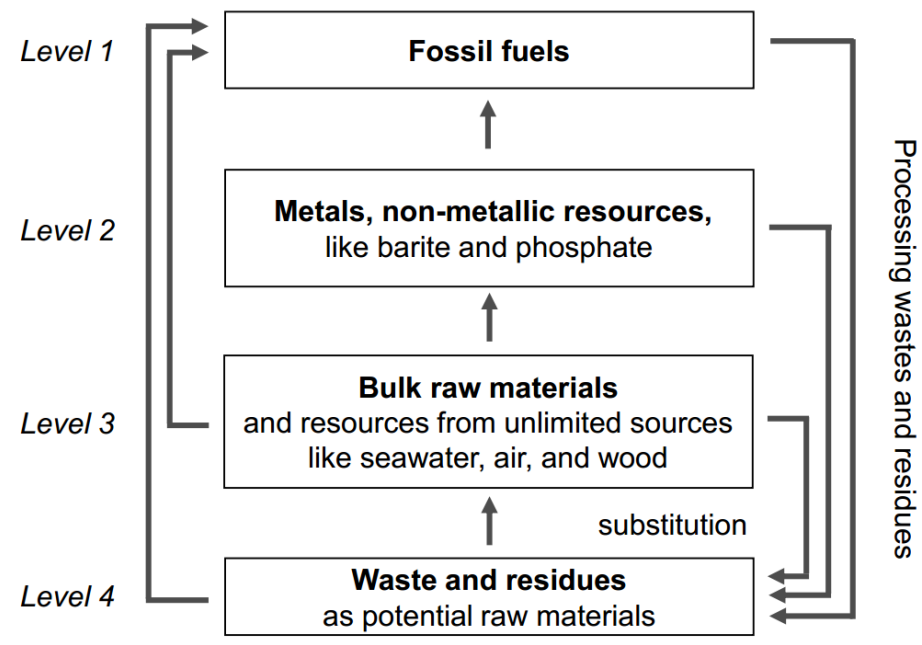

Figure 7. Hierarchy of natural resources [63]. Bulk materials on Level 3 are, for example, the construction materials, sand, gravel and limestone.

The idea presented is a resources-related system of systems thinking [64]. We argue, instead, for the need to think about one single-input and one single output; future resources management has to be viewed from a multi-variable, multi-resources, multi-subsystem systems perspective. This is explained below with a rather simple example of improving the insulation of houses (Figure 8).

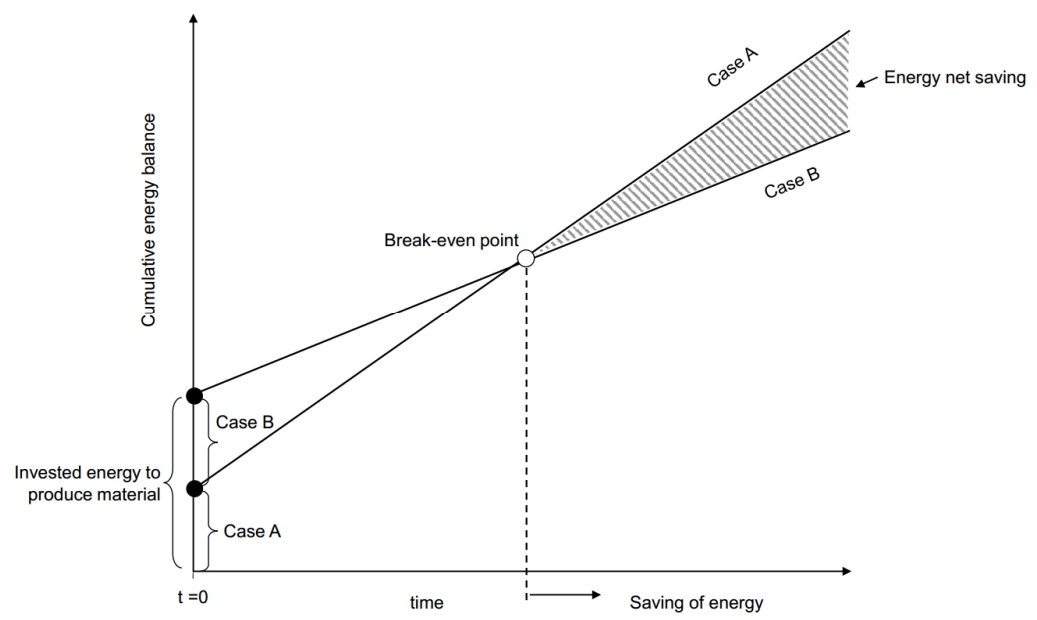

Figure 8. Cumulative energy usage over time in home heating: early investment of energy in insulating materials during construction results in a net saving of energy in the future [63]. 
Because energy resources occupy the top of this hierarchy, it makes sense to conserve energy by using more raw materials of lower ranking, rather than materials from the top levels, by applying technological substitution [65].

Insulation materials consist of raw materials, such as glass for triple-glazing instead of double-glazing, or rock wool for the improved insulation of walls, coming from primary or secondary sources. The production of these materials requires energy. Investment in energy and non-energy materials can improve energy efficiency. Schematically in Figure 8, two cases for insulating buildings are compared. Case A is the standard case. Case B benefits from a greater investment in insulating materials such as additional window glass or rock wool. The diagram in Figure 8 shows the cumulative energy balance over time. Of course, the energy input for building and insulating materials occurs only at the fabrication and construction stage and stays constant from $t=0$ onward. In the diagram for a cumulative energy balance, we have to add the energy used for heating, being zero at the beginning $(t=0)$ and rising over time. Because case B is better insulated, the consumption line is flatter and intersects at a certain point of time with the steeper consumption line of the base case A. The point of intersection is the break-even point for cases A and B, i.e., at this point in time, the additional energy invested in the production and installation of additional insulating material has been recovered through savings in using energy to heat. From the break-even point onward to the right, the total cumulative energy balance is reduced (hatched area) [64]. If we now add secondary material for glass, for example, we can save more energy und reduce the $\mathrm{CO}_{2}$-impact. The melting point for glass is lower than for the raw material quartz sand, meaning the break-even point in Figure 8 moves to the left. Glass production also requires calcium carbonate with the consequence of $\mathrm{CO}_{2}$ emission. Using secondary material, no additional carbonate, i.e., carbonate emission is necessary.

In the context of the hierarchy of natural resources (Figure 7), energy sources from Level 1 are replaced by unlimited resources from Level 3 (building material). Using unlimited resources from Level 3 requires energy, but this leads to a reduction of overall energy consumption.

In addition, the above-described changeover from fossil-fuel energies to renewable energies that requires more mineral resources per unit of energy output aligns very well with this hierarchy of natural resources with energy at the top. More resources from Level 2 and 3 are used to optimize energy at Level 1 [59-61].

\section{A New Hierarchy of Natural Resources as a Consequence of the "Energiewende"}

As discussed above, hierarchies of natural resources must also be seen as a means to reflect proactive precautionary management tools for natural resources as explained with the examples in Section 6. However, they also reflect learning processes and, therefore, a timely adjustment in the hierarchy of natural resources is proposed. This will take into account the overall importance of phosphorus and the above-discussed goal of the German "Energiewende", and it could be the blueprint for other nations. The Paris Agreement within the United Nations Framework Convention on Climate Change (UNFCC) calling for actions that result in holding the increase in the global average temperature to well below two degrees Celsius requires ambitious targets for replacing fossil fuels with renewable energies by other nations as well. This has, as a consequence, that fossil fuels will lose their overall importance; however, more natural resources of other kinds have to be used, as shown above [64]. As outlined in Section 3, fossil-fuel energies cannot be recycled (the exergy is consumed), whereas mineral resources are not consumed but used and can be recycled (atoms do not get lost). Therefore, there are no constraints for renewable energies [48].

These envisaged changing priorities concerning raw materials for producing energy call for a new concept of a hierarchy of natural resources, placing the essential fertilizer element phosphorus without unlimited availability at the top, underlining the previously discussed (see Section 5.2) need to know its geopotential to the extent possible as the source of future reserves and resources. Concepts develop at various points to consider the long-term availability under the aspect of a bioessential element without unlimited reserves. 
On the supranational level, the European Commission (EC) has thus studied and defined critical raw materials twice, in 2010 and 2014 [66]. The EC uses two indicators: economic importance and supply risk; however, it does not distinguish directly between short- and long-term issues.

For economic importance, the proportion of each material associated with industrial megasectors such as construction is combined with its gross value added to the EU's GDP (gross domestic product). This total is scaled according to the total EU GDP to define the overall economic importance of a material. For the supply risk, the World Governance Indicator (WGI) of the World Bank is used to measure the supply risks of raw materials. This indicator considers accountability, political stability and the absence of violence, government effectiveness, regulatory quality, and rule of law. These indicators reflect the situation at the time of analysis, i.e., 2010 and 2014. In 2010, 15 critical raw materials or raw material groups were defined: antimony, beryllium, cobalt, fluorspar, gallium, germanium, indium, magnesium, natural graphite, niobium, platinum group metals (PGM), heavy and light rare earth elements (REEs), tantalum and tungsten. The 2014 list includes 14 of the 15 materials identified in the previous report, with only tantalum (due to a lower supply risk) removed from the EU critical material list. Six new materials were added to the 2014-list: borates, chromium, coking coal, magnesite, silicon metal, and phosphate rock. For phosphate rock, no short-term supply problems are envisaged, but longer-term considerations and more principal aspects have been applied than for other commodities. The EC-report [66] states: "There is a high supply risk due to concentrated production from three main countries, though it is close to the supply risk threshold. Corporate concentration for this material appears relatively high compared to other materials, rising over the past five years. The economic importance is moderately high, exceeding the criticality threshold. There is no recycled input and substitution is impossible in its main application as an input to fertilizers and other chemicals."

There are other reasons why phosphorus is an exceptional case requiring special effort. The history of phosphate fertilizers is characterized by a "switch" from organic biomass and guano fertilizer to sedimentary and igneous phosphate rock fertilizers. According to statistics for countries of the European Union, $30-70 \%$ of phosphorous intake by soils is derived from manure, meaning originally biomass [67]. Increasing the application of manure has significant drawbacks, namely, the increased input of nitrogen in groundwater. Regions in Europe with intensive mass animal farming such as in the Emsland in Northern Germany face severe problems fulfilling EU-guidelines (Nitrates Directive) concerning nitrates in groundwater [68].

According to the biogeochemical properties of phosphorus [69], we cannot expect another medium (such as aquatic systems or the atmospheric system) to become a high-grade source in the long-term future. The recycling of phosphorus from wastewater may provide only $5-12 \%$ of the current total consumption of phosphate rock (if all sewage were to be processed in high-technology sewage plants [70]. The largest losses of high-grade phosphate-rock-based phosphorus takes place in today's industrialized agriculture system by runoffs, erosion, leaching, etc., and losses of phosphorus in sewage and animal carcasses [71,72]. The increase of nutrient-use efficiency is limited [73] and the shift by large-scale agriculture to closed nutrient cycles (e.g., by biomass production without open-land agriculture) is not on the horizon, even if we take a futuristic perspective of more than 300 years. Phosphorus showed the typical growth pattern of other mineral commodities in parallel with the growth of population (e.g., [74]): a slow increase from 1900 to the end of WWII, followed by a strong increase up to 1990 (nearly 6.2\% average growth rate). This phase ended with the collapse of the centrally planned economies in the east and reduced consumption in developed countries due to more efficient fertilizer input. The growth phase started again in 2001 with, until 2016, an average growth rate of nearly $5 \%[75,76]$, a slower growth rate than before 1990, reflecting a typical learning process normally mirrored in growth curves [77].

If we try to extrapolate and look at the multiple demand factors (including population development) of the annual demand of phosphorus, we may assume that the primary demand may further decline within a couple of decades. However, considering the essentiality of phosphorus 
for biomass and food production, such a decline would require a substantial increase in recycling activities for phosphorus.

On a national level, the example of Germany is given: it is a political goal of the German government to recover phosphorus from sewage sludge. There is growing resistance against applying sewage sludge directly to the field because of its heavy metal content. In the coalition agreement of the present German government, it is stated: "We will stop the sewage sludge application for fertilizing purposes and we shall recover phosphorus and other nutrients" ([78], p. 120). In January of 2017, the German Federal Cabinet passed a new sewage-sludge ordinance [79], which may go into effect on 1 January 2018. This step will make phosphorus recovery from sewage sludge obligatory for all German wastewater treatment plants (WWTPs) with larger than 50,000 person equivalents (p.e.). This means that approximately 500 WWTPs of about 9300 WWTPs will be required to recover phosphorus. They will have to recover the phosphorus if the sludge contains more than $2 \%$ phosphorus/DS (dry solids) or incinerate the sludge in mono-incinerators. Land application of sludge will be allowed only for WWTPs smaller than 50,000 p.e. These approximately 500 WWTPs represent roughly $66 \%$ of the total phosphorus removed from German wastewater and transferred into sludge [80]. The city of Hamburg, Germany recently announced plans to build the world's largest phosphorus recycling plant for waste water [81].

The recycling of phosphorus for fertilizing purposes is still not economic, with the exception of the manure route and some extraction of struvite with some methods (if the gains of extraction in the drying process of a sewage plant are taken into account). Therefore, if we compare phosphate fertilizer production from primary rock phosphate to secondary production from sewage sludge and take the hierarchy of natural resources of Figure 7 into account, we have to invest more chemicals from the raw materials at Level 2 and more energy from Level $1[82,83]$ to save primary phosphate deposits. A critical issue is that phosphate is currently a low-cost commodity. Given a price of 200 USD per ton of phosphate rock granulate, each world citizen annually pays only 6 USD for mineral P, whereas an approximate 600-700 USD is paid for energy [51]. Thus, there are very low economic incentives for recycling.

The most critical issue from a long-term perspective, however, is the distinct dissipative structure of current anthropogenic phosphorus use. If we look at the global phosphorus flows [75], about 90\% of phosphorus use is linked to food and feed production, but only the magnitude of $5 \%$ is factually consumed and $95 \%$ of the approximately $50 \mathrm{Mt} \mathrm{P}$, which is anthropogenically mobilized for food, does not land on the table. This low-use efficiency may certainly be increased by the magnitude of factor 2 in the mid-term perspective. One method might be improved precision farming methods, a management concept using detailed local soil information for applying fertilizer according to the specific need of plants $[84,85]$. Another idea to improve the phosphate resource efficiency might be to reduce phosphate losses from runoff by using artificial wetlands. This could lead to recovery as most of the phosphate is adsorbed on sediment and therefore may be recoverable by solvent extraction [86]. The processes by which phosphate cycles occur within soils are only partially understood. Increased agricultural research on ways to improve the efficiency of phosphate and minimize detrimental environmental effects is necessary to improve overall phosphate resource efficiency. However, given the current agricultural supply-demand chain, larger factors are difficult to imagine. Thus, we will face a long-term demand of rock phosphate consumption on a high level that may cover thousands of years, at least based on our current knowledge.

If we now look into the future with renewable energies replacing fossil-fuel energies, we can make the following statements concerning a new hierarchy of natural resources (Figure 9):

- Phosphate rock, as the raw material for phosphorus, should be at the top because it is bioessential and the only fertilizer element without practically unlimited reserves on Earth (given that large scale recycling of $\mathrm{P}$ from seawater remains impossible for economic reason). 
- Because of renewable energies, the different energy intensities of fertilizer resources (nitrogen produced by the Haber-Bosch process is much more energy intensive than phosphate) are not relevant for this proposed hierarchy.

- The new German directive that sewage sludge has to be recycled for phosphorus is the arrow from Level 5 to Level 1.

- Phosphorus, with its primary use in agriculture, has an exceptionally distinct dissipative structure; large shares of naturally weathered and anthropogenic phosphorus are still running to the sea.

- Even with theoretical 100-percent renewable energies, the raw materials for fossil-fuel energies will still be used as raw materials for reduction, for instance, coal in metallurgical plants or natural gas in direct-reduction plants for iron. As fossil fuels used for energy generation, they cannot be recycled.

- Raw materials for fossil-fuel energies will still be used as raw materials for plastic and synthetic material. As such, they can be recycled, e.g., via the pyrolysis route, and have a place on Level 3-like metals and other non-metallic resources that can be recycled.

- The other raw materials remain at the same levels.

The results are displayed in Figure 9.

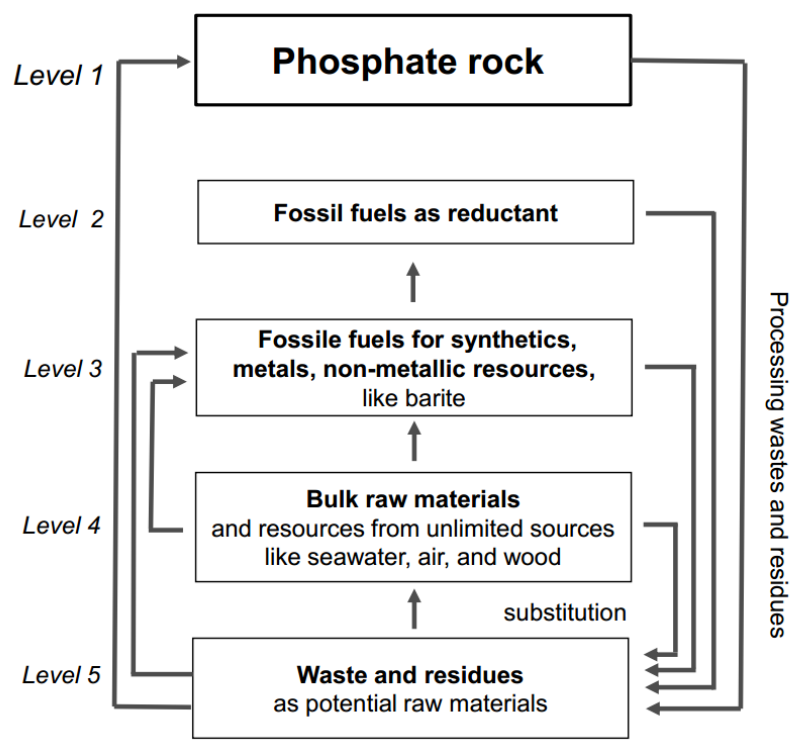

Figure 9. Concept of a new hierarchy of natural resources. Bulk materials on Level 4 are, for example, the construction materials, sand, gravel and limestone.

When we refer to a short-term perspective, we can say that the supply risk has increased in the last decade. This is indicated by the Herfindahl-Hirschmann-Index for phosphate-producing countries and for phosphate-producing companies. In addition, the country risk as indicated by WCR (weighted country risks) derived from the World Bank World Governance Indicator is increasing (Figure 10). This certainly calls for paying attention to the reduction of the risk of bottlenecks in the phosphate supply. Naturally, increasing resource efficiency by using secondary resources instead of primary ones is an important means of increasing supply security; this also has the effect of countering concentration trends of primary production. However, recycling is also an important means. Most efficient recycling can happen where there are high population concentrations as in Central Europe with a low country risk. This can be observed, for example, in The Netherlands, Switzerland or Germany, as reported above in Section 7. With the exception of the US and China, large-consumption countries are not producer countries. Therefore, an increasing share of secondary 
phosphorus guided by the hierarchy of natural resources with phosphorus at the top can decrease the supply risk, resulting in lower concentration and lower country risk.

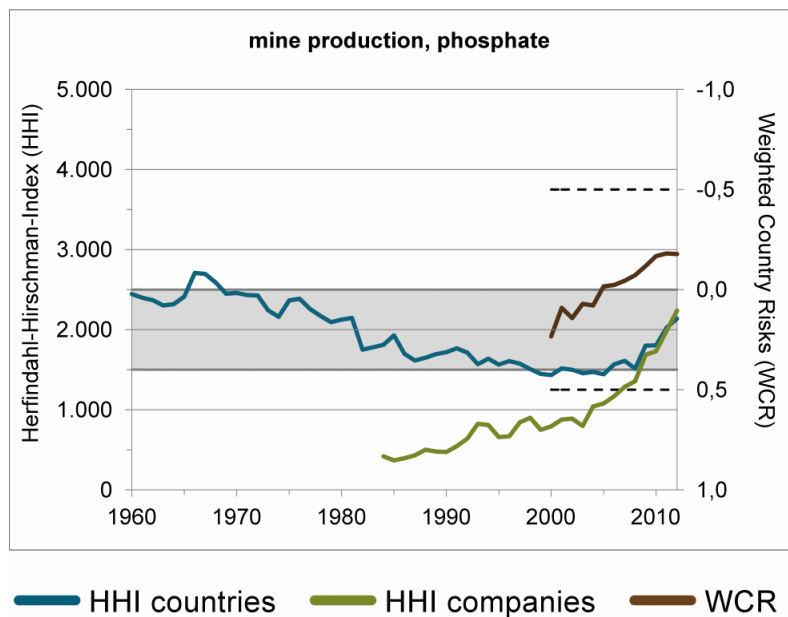

Figure 10. The Herfindahl-Hirschmann-Index (HHI) concentration index of phosphate-rock mine production for producer countries and producer companies and the weighted country risk (WCR), derived from the World Bank World Governance Indicator [87] (with permission of the DERA, Deutsche Rohstoffagentur). (The grey area is the area of average concentration, considered uncritical).

Against this backdrop, we believe that we should promote proactive, modest, precautionary management. If we refer to intergenerational equity, which became a basic world-regulating concept at the Rio Convention 30 years ago [55,88], the longtime supply security of phosphorus as a bio-essential mineral must be given the topmost position of any hierarchy of natural resources.

If we at least want to demonstrate a long-term commitment to future generations, knowledge about geopotential and future reserves may also be viewed as a basic component of environmental literacy, which is necessary if we hope to avoid hard landings and unwanted and unnecessary economic crises due to insufficient resources management.

\section{Conclusions}

Today, after more than one and a half centuries of the Industrial Age, we continue to face increases in population, energy and mineral consumption per person in most parts of the world. Human development and well-being are highly dependent on (physical) availability and (geopolitical and economic) accessibility to these resources. The global resources system has become a global system of systems in which different types of energy and different minerals serve different functions. In this context, a hierarchy of natural resources has been suggested. We suggest that this hierarchy may serve as a management tool that may help nations and humankind to anticipate and analyze potential future supply security and to prepare human key actors for proactive, modest precautionary management for resilient resources use.

Formerly, the finite resource fossil-fuel energy was placed at the top of this hierarchy, stressing that the supply seems to be essential in a mid-term perspective for avoiding critical disruptions in global world development. Fortunately, a couple of leading industrial nations have exerted tremendous efforts to develop and implement technologies for successfully substituting fossil-fuel energies on a large scale with the increasing use of efficient renewable energy.

Against this backdrop, this paper suggests that this resource hierarchy must be reconsidered and reorganized to place phosphorus in the topmost position. High-grade phosphate rock is a finite resource. Phosphorus is unsubstitutable in food production; about half of the current food production worldwide is thought to be based on phosphorus, and food-related phosphorus use efficiency is very low. Thus, there is a right to know whether or not today-and for the future-the phosphorus supply is 
secure. Due to the dissipative characteristic of the natural and anthropogenic phosphorus cycle and given the current supply chain and agricultural system, the recycling of a large share of phosphorus as well as the mining of phosphorus from other sources (water and air) with any probability close to security in the short- and mid-term future seems unlikely.

However, because there is no short-term scarcity in the next few centuries due to large phosphate reserves and resources that may be economically mined in the future, we suggest that phosphorus be placed at the top of the natural resources hierarchy. The accessibility of phosphorus is the basic pillar of the dignity related to food, i.e., of one of the most basic human rights. If we apply the principle of intergenerational equity, generations today must take responsibility for future generations by exploiting phosphate rock. Thus, we have to develop a phosphorus resources literacy that supports long-term phosphorus-supply security for future generations. This literacy includes documentation about current and potential future resources and reserves, the design of closed-loop phosphorus management (in particular in agricultural systems and food flows), and the development of new knowledge and technologies including exploration, mining, processing, use, and recycling that will make anthropogenic phosphorus accessible even if the high grade (i.e., above $15 \% \mathrm{P}_{2} \mathrm{O}_{5}$ concentration level phosphate rock) has been exploited.

Wellmer and Scholz [35] have suggested "a solidly funded, international standing committee that regularly analyzes global geopotential". Such a committee could be established under the auspices of the International Union of Geological Sciences or initially anchored at EuroGeoSurveys (the Association of the European Geological Surveys). Here, a transdisciplinary process involving international science organization and governmental earth-science organizations may be meaningful, as the basic data produced should not be biased by economic or national interests. Although the focus should be on future supply security (i.e., intergenerational equity), there are at least two issues of interest with respect to intragenerational equity related to phosphorus as postulated by Agenda 21 [88]. To the intergenerational equity concept of the UN Brundtland Report [55], Agenda 21 added three humanitarian objectives - all three initially with the same priority - to conserve the basic needs of life, to enable all people to achieve economic prosperity, and to strive towards social justice. One precondition is sufficient food for everyone on the planet. Therefore, there has to be a right of the poor (e.g., sub-Saharan smallholder farmers) to gain access and to benefit from phosphorus. Another is that - as is the case with many minerals - the production of phosphate rock has become increasingly more concentrated (Figure 10) [87] and takes place in only a few countries, some of which may be exposed to political instability. We have shown that, according to different indicators (see Figure 10), the country and company concentration risks of the phosphorus rock supply is increasing. Thus, the monitoring of short-term supply risks also calls for attention. The proposed committee, therefore, should also monitor concentration trends on the supply side, taking into account country risks and primary and secondary sources.

A final remark concerning better knowledge about resources and geopotential: it will have an influence on the public concern about future food security, but it will probably have no or very little influence on the growing resistance against mining, meaning the influence of the availability EY, in its annual analysis of the business risks facing mining and metals has listed the risk "social license to operate" among the top four or five mining risks for the past 10 years [89]. Knowledge about reserves, resources or geopotential does not make mining more acceptable [90]. Other ways and means have to be found to solve this problem (e.g., [91]).

Acknowledgments: We want to thank Magnus Ericsson, , Christian Kabbe, Joyce A. Ober and two unnamed reviewers for their helpful comments, Bernhard Geissler for comments and helping with Figure 4 and Elaine Ambrose for the English editing.

Author Contributions: Both authors contributed equally to this work. The conception of the paper was jointly discussed and emerges from joint previous papers of the authors. Friedrich-W. Wellmer wrote the first draft of most sections, but several sections such as Section 4, major parts of Section 7 were written by Roland W. Scholz. Both authors contributed to the finalizing of the text and the revisions. 
Conflicts of Interest: The authors declare no conflict of interest.

\section{References}

1. Wellmer, F.-W. Rohstoffversorgung und Geologische Dienste-Wandel der Aufgaben in den letzten 100 Jahren (Raw material supply and geological surveys, changes in the task during the last 100 years). Erzmetall 1995, 48, 608-617.

2. British Geological Survey. Our Past. Available online: http://www.bgs.ac.uk/about/ourPast.html (accessed on 4 February 2017).

3. Fors, H. The Limits of Matter: Chemistry, Mining and the Enlightment; University of Chicago Press: Chicago, IL, USA, 2015.

4. Alfaro, J.C.; Corcoran, C.; Davies, K.; Gonzalez-Pineda, F.; Hampson, G.; Hill, D.; Howard, M.; Kapoor, J.; Moldoveanu, N.; Kragh, E. Reducing Exploration Risk. In Oilfield Review 2007; Schlumberger: Houston, TX, USA; pp. 26-43.

5. Repsol. Repsol reports above-average drilling success in 2013. Available online: http://www. naturalgaseurope.com/repsolreports-39-drilling-success-rate (accessed on 23 July 2014).

6. BP Educational Service. The science of searching. Available online: http://www.bp.com/en/ global/corporate/about-bp/what-we-do/finding-oil-and-gas/thescienceof-searching.html (accessed on 23 July 2014).

7. Fustier, K.; Gray, G.; Gundersen, C.; Hilbott, T. Global Oil Supply: Will Mature Field Declines Drive the Next Supply Crunch? HSBC Global Research. September 2016. Available online: https:/ /de.scribd.com/ document/335917074/HSBC-Peak-Oil-Report-2017 (accessed on 8 February 2017).

8. Kreuzer, O.P.; Etheridge, M.A. Risk and Uncertainty in Mineral Exploration: Implications for Valuing Mineral Exploration Properties. Available online: http://www.academia.edu/download/30898732/Kreuzer Etheridge_2010_Risk_and_uncertainty_in_exploration_-_implications_for_project_valuation.pdf (accessed on 1 June 2017).

9. Sames, W.; Wellmer, F.-W. Exploration I: Nur wer wagt, gewinnt-Risiken, Strategien, Aufwand, Erfolg. Glückauf 1981, 117, 580-589.

10. Scholz, R.; Wellmer, F.-W.; DeYoung, J.H., Jr. Phosphorus Losses in Production Processes before the "Crude Ore" and "Marketable Production" Entries in Reported Statistics. In Sustainable Phosphorus Management: A Global Transdisciplinary Roadmap; Scholz, R., Roy, A.H., Brand, F.S., Hellums, D.T., Ulrich, A.E., Eds.; Springer: Dordrecht, The Netherlands, 2014; pp. 174-182.

11. Wellmer, F.-W. Reserves and resources of the geosphere, terms so often misunderstood. Is the life index of reserves of natural resources a guide to the future? Z. Dtsch. Ges. Geowiss. 2008, 159, 575-590. [CrossRef]

12. U.S. Department of the Interior; U.S. Geological Survey. Mineral Commodity Summaries 2016; U.S. Geological Survey: Washington, DC, USA, 2016; p. 202.

13. Thom, W.T., Jr. Petroleum and Coal, the Keys to the Future; Princeton University Press: Princeton, NJ, USA, 1929.

14. McKelvey, V.E. Mineral resource estimates and public policy. Am. Sci. 1972, 60, 32-40.

15. Zwartendyk, J. What is "mineral endowment" and how should we measure it? In Canadian Uranium Resource and Production Capability; Wiliams, R.M., Little, H.W., Eds.; Mineral Bulletin MR 126; Department of Energy, Mines and Resources (Mineral Resources Branch): Ottawa, ON, Canada, 1972.

16. United Nations Framework Classification for Fossil Energy and Mineral Reserves and Resources, 2009. ECA Energy Series No. 39 United Nations Economic Commission for Europe. Available online: http: / / www.unece.org/energy/se/unfc_2009.html (accessed on 10 July 2016).

17. Wellmer, F.-W. Risk elements characteristic of mining investments. In Proceedings of the 13th Council of Mining and Metallurgical Institutions Congress, Singapore, 11-16 May 1986; Volume 5, pp. 17-24.

18. Joint Ore Reserves Committee. The JORC Code. Available online: http://www.jorc.org/aaa (accessed on 31 January 2017).

19. Canadian Institute of Mining and Metallurgy. Standards and Guidelines for Reserves and Resources. National Instrument 43-101. Available online: http:/ / web.cim.org/standards/menupage.cfm?sections=177, $181 \&$ menu=229 (accessed on 31 January 2017).

20. Wellmer, F.-W.; Leifeld, D.; Röhling, S.; Wagner, H. Mineral and energy resources: Economic factor and motor for research and development. Z. Dtsch. Ges. Geowiss. 2003, 154, 1-27. 
21. Sillitoe, R.H. Exploration and Discovery of Base-and Precious-Metal Deposits in the Circum Pacific Region During the Last 25 Years; Metal Mining Agency of Japan: Tokyo, Japan, 1995; pp. 1-119.

22. Heiberg, S.; Wellmer, F.-W. Stretching the Availability of Non-renewable Resources. In Non-Renewable Resource Issues; Sinding-Larsen, R., Wellmer, F.-W., Eds.; Springer: Dordrecht, The Netherlands, 2012; pp. 183-194.

23. Wellmer, F.-W.; Hagelüken, C. The Feedback Control Cycle of Mineral Supply, Increase in Raw Material Efficiency, and Sustainable Development. Minerals 2015, 5, 815-836. [CrossRef]

24. Arnon, D.I.; Stout, P.R. The essentiality of certain elements in minute quantity for plants with special reference to copper. Plant Physiol. 1939, 14, 371-375. [CrossRef] [PubMed]

25. Ernst, W.G. Global equity and sustainable resource consumption requires super-efficient extraction-conservation-recycling and ubiquitous, inexpensive energy. Intern. Geol. Rev. 2002, 44, 1072-1091. [CrossRef]

26. Rosas, J.; Schuffeneger, C.; Cornejo, C. Update of Chilean Mining Projects and Technological Trends. In Proceedings of the 44th Annual Canadian Mineral Processors Operators Conference, Ottawa, ON, Canada, 17-19 January 2012.

27. U.S. Department of Energy. Critical Materials Strategy, Washington DC 2011. Available online: http: / / energy.gov/sites/prod/files/DOE_CMS2011_FINAL_Full.pdf (accessed on 27 June 2014).

28. International Energy Agency (IEA). World Energy Outlook 2016. Available online: https://www.iea.org/ newsroom/news/2016/november/world-energy-outlook-2016.html (accessed on 10 February 2017).

29. World Energy Council. World Energy Scenarios 2016-The Grand Transition. Available online: https: / /www.worldenergy.org/publications/2016/world-energy-scenarios-2016-the-grand-transition/ (accessed on 10 February 2017).

30. DWA Bayern. Betrieb von Abwasseranlagen. Die Phosphorbilanz im kommunalen Abwasser, Leitfaden Nr. 2-13; München, Germany, Unpublished work, 2011.

31. Pecod, M.B. Wastewater Treatment and Use in Agriculture; FAO Irrigation and Drainage paper 47; FAO: Rome, Italy, 1992.

32. Mainstone, C.P.; Parr, W. Phosphorus in rivers-Ecology and management. Sci. Total Environ. 2002, 282-283, 25-47. [CrossRef]

33. Guildford, S.J.; Hecky, R.E. Total nitrogen, total phosphorus, and nutrient limitation in lakes and oceans: Is there a common relationship? Limnol. Oceanogr. 2000, 45, 1213-1223. [CrossRef]

34. Scholz, R.; Wellmer, F.-W. Approaching a dynamic view on the availability of mineral resources: What can we learn from the case of phosphorous? Global Environ. Change 2013, 23, 11-27. [CrossRef]

35. Wellmer, F.-W.; Scholz, R.W. The Right to Know the Geopotential of Minerals for Ensuring Food Supply Security. J. Ind. Ecol. 2015, 19, 3-6. [CrossRef]

36. Chapple, E.D.; Coon, C.S. Principles of Anthropology; Henry Holt: New York, NY, USA, 1953.

37. Scholz, R.W. Environmental Literacy in Science and Society: From Knowledge to Decisions; Cambridge University Press: Cambridge, UK, 2011.

38. Wellmer, F.-W.; Dalheimer, M. The Feedback Control Cycle as regulator of past and future mineral supply. Miner. Deposita 2012, 47, 713-729. [CrossRef]

39. UNHR. United Nations Human Rights Office of the High Commissioner. International Covenant on Economic, Social and Cultural Rights of 3 January 1976. Available online: http://www.ohchr.org/EN/ ProfessionalInterest/Pages/CESCR.aspx (accessed on 16 August 2016).

40. Collins-Chobanian, S. Beyond Sax and welfare interests: A case for environmental rights. Environ. Ethics 2000, 22, 133-148. [CrossRef]

41. Donelly, J. The Relative Universality of Human Rights. Hum. Rights Q. 2007, 29, 281-306. [CrossRef]

42. Lahmeyer, C. Das Magazinkornwesen des oberharzer Bergbaus in seiner geschichtlichen Entwicklung und jetzige Gestaltung. Z. Bergr. 1889, 30, 86-105.

43. Wisotzky, K. Protestaktionen im Oberharzer Bergbau 1660-1738. Der Anschnitt 1987, 39, 211-228.

44. Emerson, T.I. Legal foundations of the right to know. Law Q. 1976, 1, 1-24.

45. Foerstel, H.N. Freedom of Information and the Right to Know: The Origins and Applications of the Freedom of Information Act; Greenwood Press: Westport, CT, USA, 1999.

46. United States Supreme Court. Stanley v. Georgia, (1969). No. 293. Argued: Decided: April 7, 1969. Available online: http:/ / caselaw.findlaw.com/us-supreme-court/394/557.html (accessed on 1 June 2017). 
47. Wellmer, F.-W.; Scholz, R.W. The Right to Know the Geopotential of Minerals for Ensuring Food Supply Security. J. Ind. Ecol. 2015, 19 (Supplementary Materials), 3-6. [CrossRef]

48. ESYS. Energy systems of the future, a joint project of acatech-National Academy of Science and Engineering, German National Academy of Sciences Leopoldina. Union of the German Academies of Sciences and Humanities. Raw Materials for the Energy Systems of the Future-Roads for a Secure and Sustainable Supply with Raw Materials. Position paper (in German), acatech, Munich 2017. Available online: www. acatech.de/rohstoffe-fuer-die-energiewende (accessed on 8 February 2017).

49. Jasinski, S.M. Phosphate Rock; Mineral Commodity Summaries 2016; U.S. Geological Survey: Reston, VA, USA, 2016; pp. 124-125.

50. Edixhoven, J.D.; Gupta, J.; Savenije, H.H.G. Recent revisions of phosphate rock reserves and resources: A critique. Earth Syst. Dynam. 2014, 5, 491-507. [CrossRef]

51. Scholz, R.W.; Wellmer, F.-W. Comment on: "Recent revisions of phosphate rock reserves and resources: A critique by Edixhoven et al. (2014)—Clarifying comments and thoughts on key conceptions, conclusions and interpretation to allow for sustainable action". Earth Syst. Dynam. 2016, 7, 103-117.

52. Mew, M.C. Phosphate rock costs, prices and resources interaction. Sci. Total Environ. 2016, 542, 1008-1012. [CrossRef] [PubMed]

53. Cook, P.J.; Shergold, J.H. Phosphate Deposits of the World; Cambridge University Press: Cambridge, UK, 1986.

54. Krauss, U.H.; Saam, H.G.; Schmidt, H.W. International Strategic Minerals Inventory Summary Report-Phosphate; U.S. Geological Survey Information Circular 930-C; U.S. Geological Survey: Alexandria, VA, USA, 1984.

55. Brundtland, G.H. Our Common Future. Report of the World Commission on Environment and Development; Oxford University Press: Oxford, UK, 1987.

56. Bradshaw, A.M.; Reuter, B.; Hamacher, T. The Potential Scarcity of Rare Elements for the Energiewende. Green 2013, 3, 93-111. [CrossRef]

57. Deutsche Bundesregierung. Energiekonzept für Eine Umweltschonende, Zuverlässige und Bezahlbare Energieversorgung. Berlin. 28 September 2010. Available online: www.bundesregierung.de/ContentArchiv/ DE/Archiv17/_Anlagen/2012/02/energiekonzept-final.pdf?__blob=publicationFile\&v=5 (accessed on 12 February 2017).

58. Umweltbundesamt. Rohstoffproduktivität. Available online: http://www.umweltbundesamt.de/daten/ rohstoffe-als-ressource/rohstoffproduktivitaet\#textpart-1 (accessed on 19 March 2017).

59. Vidal, O.; Goffé, B.; Arndt, N. Metals for a low-carbon society. Supplementary Information. Nat. Geosci. 2013, 6, 894-896. [CrossRef]

60. Hertwich, E.G.; Gibojn, T.; Bouman, E.A.; Arvesen, A.; Suh, S.; Heath, G.A.; Bergesen, J.D.; Ramirez, A.; Vega, M.I.; Shi, L. Integrated life-cycle Assessment of Electricity-Supply Scenarios confirms global environmental Benefit of low-carbon Technologies. Proc. Natl. Acad. Sci. USA 2014. [CrossRef]

61. Davidsson, S.; Grandell, L.; Wachtmeister, H.; Höök, M. Growth curves and sustained commissioning modelling of renewable energy: Investigating resource constraints for wind energy. Energy Policy 2014, 73, 767-776. [CrossRef]

62. Kaufmann, D.; Kraay, A.; Mastruzzi, M. The Worldbank Governance Indicators: Methodology and analytical issues. Hague J. Rule Law 2011, 3, 220-246. [CrossRef]

63. Wagner, M.; Wellmer, F.-W. A hierarchy of natural resources with respect to sustainable development-A basis for a natural resources efficiency indicator. In Mining, Society and a Sustainable World; Richards, J.P., Ed.; Springer: Berlin/Heidelberg, Germany, 2009; pp. 91-121.

64. Samad, T.; Parisini, T. Systems of systems. IEEE Control Syst. Soc. 2011, 12, 175-183.

65. Schebek, L.; Becker, B.F. Substitution von Rohstoffen-Rahmenbedingungen und Umsetzung. In Strategische Rohstoffe-Risikovorsorge; Kausch, P., Bertau, M., Gutzmer, J., Matschullat, J., Eds.; Springer: Berlin/Heidelberg, Germany, 2014; pp. 3-12.

66. European Commission. Report on critical raw materials for the EU. Report of the Ad hoc Working Group on defining critical raw materials. May 2014. Available online: https://ec.europa.eu/growth/sectors/rawmaterials/specific-interest/critical_de (accessed on 12 February 2017).

67. Schröder, J.; Cordell, D.; Smit, A.L.; Rosemarin, A. Sustainable Use of Phosphorus; SEI Report 357; EU Tender ENV.B. 1/ETU/2009/0025; Plant Research International: Wageningen, The Netherlands, 2010.

68. European Commission. The Nitrates Directive. Available online: http://ec.europa.eu/environment/water/ water-nitrates/index_en.html (accessed on 12 May 2017). 
69. Ruttenberg, K.C. The global phosphorus cycle. In Treatise on Geochemistry; Holland, H.D., Turekian, K.K., Eds.; Elsevier: New York, NY, USA, 2003; pp. 585-643.

70. Scholz, R.W.; Wellmer, F.-W. Losses and use efficiencies along the phosphorus cycle-Part 1: Dilemmata and losses on the mines and other nodes of the supply chain. Resour. Conserv. Recycl. 2015, 105, 216-234. [CrossRef]

71. Lamprecht, H.; Lang, D.J.; Binder, C.R.; Scholz, R.W. The Trade-Off between Phosphorus Recycling and Health Protection during the BSE Crisis in Switzerland. A “Disposal Dilemma". Gaia Ecol. Perspect. Sci. Soc. 2011, 20, 112-121. [CrossRef]

72. Schoumans, O.F.; Bouraoui, F.; Kabbe, C.; Oenema, O.; van Dijk, K.C. Phosphorus management in Europe in a changing world. Ambio 2015, 44, 180-192. [CrossRef] [PubMed]

73. Scholz, R.W.; Wellmer, F.-W. Losses and use efficiencies along the phosphorus cycle-Part 2: Understanding the concept of efficiency. Resour. Conserv. Recycl. 2015, 105, 259-274. [CrossRef]

74. Krausmann, F.; Gingrich, S.; Eisenmenger, N.; Erb, K.-H.; Haberl, H.; Fischer-Kowalski, M. Growth in global materials, GDP and population during the 20th century. Ecol. Econ. 2009, 10, 2696-2705. [CrossRef]

75. U.S. Department of the Interior; U.S. Geological Survey. Mineral Commodity Summaries 2017; USGS: Washington, DC, USA, 2017.

76. BGR Databank 2017. Available online: http://databank.worldbank.org/data/databases/\%26nbsp; economic-growth?qterm=\&pagenumber=2 (accessed on 20 May 2017).

77. Wellmer, F.-W.; Dalheimer, M.; Wagner, M. Economic Evaluations in Exploration; Springer: Berlin/Heidelberg, Germany, 2008; p. 187.

78. CDU, CSU, SPD (Christlich Demokratische Union Deutschlands/Christlich-Soziale Union in Bayern/Sozialdemokratische Partei Deutschland). Deutschlands Zukunft Gestalten (Coalition Agreement between CDU, CSU und SPD, 18. Legislative Period 6 December 2013); Coalition parties of the Federal Government: Berlin, Germany, 2013.

79. Bundesministerium für Umwelt, Naturschutz, Bau und Reaktorsicherheit. Deutschland soll Phosphor aus Klärschlamm Gewinnen. Press News No. 017/17 of 18 January 2017. Available online: http:/ / www.bmub.bund.de/presse/pressemitteilungen/pm/artikel/deutschland-soll-phosphoraus-klaerschlamm-gewinnen/?tx_ttnews\%5BbackPid\%5D=82 (accessed on 12 February 2017).

80. Kraus, F.; Kabbe, C. Klärschlamm: Phosphorstrategie infolge neuer rechtlicher Regelungen. In Proceedings of the DWA (Hrsg.) Klärschlamm: Neue Strategien und Techniken, Wasserwirtschaftskurs P/4, Kassel, Germany, 9-11 November 2016; pp. S50-S70.

81. Deutsche Phosphor-Plattform kündigt Informations-Strategie zur Phosphor-Kreislaufführung an. Available online: www.euwid-wasser.de/.../hamburg-wasser-plant-bau-von-grosstechnischer-anlage-fue (accessed on 12 May 2017).

82. Petzet, S. Phosphorrückgewinnung in der Abwassertechnik-Neue Verfahren für Klärschlamm und Klärschlammaschen. Ph.D. Thesis, Technical University of Darmstadt, Darmstadt, Germany, 2012.

83. Kabbe, C.; Kraus, F.; Remy, C. Review of promising methods for phosphorus recovery and recycling from wastewater. In Proceedings of the International Fertiliser Society, London, UK, 23-24 June 2015; pp. 1-29.

84. Scholz, R.W.; Roy, A.H.; Hellums, D.T. Sustainable phosphorus management: A global transdisciplinary challenge. In Sustainable Phosphorus Management: A Global Transdisciplinary Roadmap; Scholz, R.W., Roy, A.H., Brand, F.S., Hellums, D.T., Ulrich, A.E., Eds.; Springer: Dordrecht, The Netherlands, 2014; pp. 1-129.

85. Rickmann, D.; Luvall, J.C.; Shaw, J.; Mask, P.; Kissel, D.; Sullivan, D. Precision Agriculture: Changing the Face of Farming. Geotimes 2003, 48, 28-31.

86. Brady, N.C.; Weil, R.R. The Nature and Properties of Soils; Pearson Prentice Hall: Upper Saddle River, NJ, USA, 2008.

87. DERA Deutsche Rohstoffagentur. DERA-Rohstoffliste 2014-Angebotskonzentration bei Mineralischen Rohstoffen und Zwischenproduktion-Potenzielle Preis-und Lieferrisiken; DERA Rohstoffinformationen 24; DERA: Berlin, Germany, 2015.

88. United Nations Sustainable Development. United Nations Conference of Environment and Development. Rio de Janeiro, Brazil 3-14 June 1992. Agenda 21. Available online: https://sustainabledevelopment.un.org/ content/documents/Agenda21.pdf (accessed on 21 March 2017). 
89. EY. Top 10 business risks facing mining and metals 2016-2017. Available online: http: / /www.ey.com/Publication/vwLUAssets/EY-business-risks-in-mining-and-metals-2016--2017/ \%24FILE/EY-business-risks-in-mining-and-metals-2016--2017.pdf (accessed on 12 May 2017).

90. Obers, J. Re phosphate mining in Florida/USA. Personal communication, 2017.

91. Parsons, R.; Moffat, K. Constructing the Meaning of Social License. Soc. Epistemol. 2014, 28, 340-363. [CrossRef]

(c) (C) 2017 by the authors. Licensee MDPI, Basel, Switzerland. This article is an open access article distributed under the terms and conditions of the Creative Commons Attribution (CC BY) license (http://creativecommons.org/licenses/by/4.0/). 